\title{
Importance of Melatonin in Assisted Reproductive Technology and Ovarian Aging
}

\author{
Hiroshi Tamura ${ }^{1, *}$, Mai Jozaki ${ }^{1}$, Manabu Tanabe ${ }^{2}$, Yuichiro Shirafuta ${ }^{1}$, Yumiko Mihara ${ }^{1}$, \\ Masahiro Shinagawa ${ }^{1}$, Isao Tamura ${ }^{1}$, Ryo Maekawa ${ }^{1}{ }^{1}$, Shun Sato ${ }^{1}$, Toshiaki Taketani ${ }^{1}$, \\ Akihisa Takasaki ${ }^{2}$, Russel J. Reiter ${ }^{3}$ and Norihiro Sugino ${ }^{1}$ \\ 1 Department of Obstetrics and Gynecology, Yamaguchi University Graduate School of Medicine, \\ Minamikogushi 1-1-1, Ube 755-8505, Japan; mkawa@yamaguchi-u.ac.jp (M.J.); \\ yshirafu@yamaguchi-u.ac.jp (Y.S.); andy-yu@yamaguchi-u.ac.jp (Y.M.); mshina@yamaguchi-u.ac.jp (M.S.); \\ isao@yamaguchi-u.ac.jp (I.T.); rmaekawa@yamaguchi-u.ac.jp (R.M.); shnstymg@yamaguchi-u.ac.jp (S.S.); \\ taketani@yamaguchi-u.ac.jp (T.T.); sugino@yamaguchi-u.ac.jp (N.S.) \\ 2 Department of Obstetrics and Gynecology, Saiseikai Shimonoseki General Hospital, Yasuokacho 8-5-1, \\ Shimonoseki 759-6603, Japan; my071123my@yahoo.co.jp (M.T.); a-takasaki@simo.saiseikai.or.jp (A.T.) \\ 3 Department of Cellular and Structural Biology, The University of Texas Health Science Center, San Antonio, \\ TX 78229, USA; reiter@uthscsa.edu \\ * Correspondence: hitamura@yamaguchi-u.ac.jp; Tel.: +81-836-22-2288; Fax: +81-836-22-2287
}

Received: 8 January 2020; Accepted: 6 February 2020; Published: 8 February 2020

\begin{abstract}
Melatonin is probably produced in all cells but is only secreted by the pineal gland. The pineal secretion of melatonin is determined by the light-dark cycle, and it is only released at night. Melatonin regulates biological rhythms via its receptors located in the suprachiasmatic nuclei of the hypothalamus. Melatonin also has strong antioxidant activities to scavenge free radicals such as reactive oxygen species (ROS). The direct free radical scavenging actions are receptor independent. ROS play an important role in reproductive function including in the ovulatory process. However, excessive ROS can also have an adverse effect on oocytes because of oxidative stress, thereby causing infertility. It is becoming clear that melatonin is located in the ovarian follicular fluid and in the oocytes themselves, which protects these cells from oxidative damage as well as having other beneficial actions in oocyte maturation, fertilization, and embryo development. Trials on humans have investigated the improvement of outcomes of assisted reproductive technology (ART), such as in vitro fertilization and embryo transfer (IVF-ET), by way of administering melatonin to patients suffering from infertility. In addition, clinical research has examined melatonin as an anti-aging molecule via its antioxidative actions, and its relationship with the aging diseases, e.g., Alzheimer's and Parkinson's disease, is also underway. Melatonin may also reduce ovarian aging, which is a major issue in assisted reproductive technology. This review explains the relationship between melatonin and human reproductive function, as well as the clinical applications expected to improve the outcomes of assisted reproductive technology such as IVF, while also discussing possibilities for melatonin in preventing ovarian aging.
\end{abstract}

Keywords: melatonin; ovarian aging; reactive oxygen; oxidative stress; infertility

\section{Introduction}

Melatonin is an indoleamine (molecular weight 232.3) produced by all cells including those in the pineal gland, located in the posterior wall of the third ventricle [1]. Melatonin is rhythmically released by the pineal gland such that it is mostly secreted during the night. This rhythm is controlled by the light-dark cycle, with light inhibiting melatonin synthesis and release. The circadian cycle of melatonin plays major roles in the regulation of body temperature, the secretion of various reproductively 
active hormones, and the circadian sleep-wake cycle [2]. Melatonin, which is both fat-soluble and water-soluble, is distinctive in that it can easily pass through cell membranes. It is not only present in the blood but also in body fluids, including cerebrospinal fluid, follicular fluid, and seminal vesicle fluid [3]. Melatonin receptors are found in numerous organs, and in addition to their own biorhythms, they determine, via several signaling mechanisms, secretion of various hormones, immune functions, lipid and glucose metabolism, as well as bone metabolism [4-9]. These rhythms are involved in aging, carcinogenesis, and a number of diseases [4,10-16]. Clinical research is underway in various fields including the application of melatonin in treating biological rhythm abnormalities, glucose and lipid metabolism disorders, immunoregulation, anticancer effects and aging-related diseases (Parkinson's and Alzheimer's disease) [17-21].

In addition to its receptor-mediated actions, melatonin's ability to act as a direct free radical scavenger and as an indirect antioxidant has greatly broadened understanding of the mechanisms by which melatonin benefits reproductive physiology. Melatonin has potent antioxidative capacity to remove both reactive oxygen species (ROS) and reactive nitrogen species (RNS) [22]. As already noted, the scavenging actions are a direct effect and require no receptor mediation.

\section{Antioxidative Effects of Melatonin}

In 1993, the discovery of melatonin as an antioxidant was achieved [23,24]. Melatonin is a direct free radical scavenger with more powerful antioxidant potential than conventional antioxidants such as vitamin C and E, mannitol, and glutathione [25]. Melatonin is both fat and water soluble, and can pass easily through cell membranes [26]. Therefore, it exists in the cytosol as well as in mitochondria and nuclei [27-30]. Melatonin, through direct scavenging and indirect antioxidant actions, limits oxidative stress in all cells and protects DNA and other components from damages [31,32]. The antioxidative actions of melatonin and its metabolites are extremely vast, including the ability to neutralize superoxide anion $\left(\mathrm{O}_{2}{ }^{\bullet-}\right)$, hydroxyl radical $\left({ }^{\bullet} \mathrm{OH}\right)$, single oxygen $\left({ }^{1} \mathrm{O}_{2}\right)$, hydrogen peroxide $\left(\mathrm{H}_{2} \mathrm{O}_{2}\right)$, hypochlorous $\operatorname{acid}(\mathrm{HOCl})$, nitric oxide $(\mathrm{NO})$, and peroxynitrite anion $\left(\mathrm{ONOO}^{-}\right)$[33]. Melatonin is a valuable substance that particularly detoxifies the hydroxyl radical $\left({ }^{\bullet} \mathrm{OH}\right)$, which is highly reactive and toxic. When melatonin eliminates free radicals, it is converted to metabolites including cyclic 3-hydroxmelatonin (C3OHM), N1-acetyl-N2-formyl-5-methoxykynuramine (AFMK) and N1-acetyl-5-methoxykynuramine (AMK). These metabolites, like melatonin, have potent antioxidative actions [34]. Melatonin also indirectly increases antioxidant enzyme activity including superoxide dismutase (SOD) and glutathione peroxidase (GPx), and increases both antioxidant enzyme activity and mRNA expression via the membrane receptors of melatonin (MT1, MT2) [35].

\section{Reactive Oxygen and Reproductive Function}

ROS have important roles in reproductive processes such as influencing follicular growth, oocyte maturation, ovulation, fertilization, embryo implantation, and embryo development [36]. During ovulation, following a surge of luteinizing hormone (LH) that induces the release of ova, large amounts of ROS are generated by vascular endothelial cells and macrophages as neovascularization progresses within the follicles. The ROS generated within follicles provides the stimulation needed for oocyte maturation and follicular rupture. Excessive ROS, however, cause cytotoxicity. As a defense mechanism against ROS, there are antioxidative enzymes and antioxidants present in follicles and in the oocytes themselves [37], which protect oocytes and granulosa cells from oxidative stress. If an imbalance between ROS concentrations and antioxidant activities occurs, oocytes and granulosa cells are readily damaged due to oxidative stress, which results in poor oocyte quality. Studies have reported that in mice after the induction of ovulation with human chorionic gonadotropin (hCG) following stimulation of superovulation using pregnant mare serum gonadotropin (PMSG), increased concentrations of 8-hydroxy-2'-deoxyguanosine (8-OHdG), a marker of DNA damage, and of hexanoyl-lysine (HEL), a marker of lipid peroxidation, prior to ovulation were measured [38]. Also, in humans, it has been reported that patients undergoing in vitro fertilization (IVF) with a high rate of denatured oocytes 
(poor oocyte quality) exhibit a high levels of 8-OHdG in the follicular fluid; also, low fertilization rates were noted for oocytes retrieved from follicles with an elevated concentration of 8-OHdG in the follicular fluid [39]. Thus, it appears that ROS generated during the ovulatory process is a source of oxidative stress to oocytes, in follicles, as well as granulosa cells, providing an explanation for reduced oocyte quality and infertility.

\section{Melatonin in the Ovaries}

It is becoming clear that melatonin acts directly on the ovaries [40]. In a report that examined tissue penetration of melatonin in cats, it was found that, compared to other organs, the accumulation was highest in the ovaries [41]. Melatonin also is found at a high concentrations in human follicular fluid, and it increases in proportion to follicular growth [42]. Hence, there is a mechanism whereby melatonin is taken up into the follicles as they enlarge. The physiological significance as to why melatonin is taken up into follicles and is present at high concentrations in follicles has long been unclear. Since ovulation is perceived as a phenomenon that resembles inflammation, and as a defense mechanism against ROS generated in follicles, antioxidative enzymes and antioxidants, including melatonin, protect oocytes and granulosa cells from oxidative damage. It is highly likely that melatonin carries out major roles as an antioxidant in both follicles and oocytes. In a study of follicular fluid collected during oocyte retrieval from women who have undergone IVF-ET, there were no marked correlations observed between the concentration of 8-OHdG and antioxidative enzymes, including copper $(\mathrm{Cu})$ and zinc (Zn) superoxide dismutase (Cu, Zn-SOD), as well as for glutathione; however, a significantly negative correlation was observed between the concentration of melatonin and 8-OHdG [39]. Furthermore, in patients who received melatonin ( $3 \mathrm{mg} /$ day, taken at 22:00), the levels of melatonin in follicular fluid significantly increased compared to the period when melatonin was not given as a supplement, and 8-OHdG concentrations were significantly decreased as a result of melatonin administration [39]. These results suggest that melatonin reduces oxidative stress in ovarian follicles via its antioxidative action, thereby protecting oocytes and granulosa cells.

Tanabe et al. reported that melatonin protects granulosa cells from ROS by reducing oxidative stress of cellular components including nucleus, mitochondria, and cell membranes [43]. Mouse granulosa cells were incubated with $\mathrm{H}_{2} \mathrm{O}_{2}(0.1-10 \mathrm{mM})$ in the presence or absence of melatonin (100 $\mu \mathrm{g} / \mathrm{mL})$. DNA damage (8-OHdG and $\gamma \mathrm{H} 2 \mathrm{AX})$, mitochondrial dysfunction, and lipid peroxidation of membranes (HEL) were elevated after $\mathrm{H}_{2} \mathrm{O}_{2}$ treatment, whereas these harmful effects of ROS on cellular components were alleviated by melatonin supplementation. Moreover, $\mathrm{H}_{2} \mathrm{O}_{2}$ treatment increased the number of apoptotic cells and caspase 3/7 (Csp3/7) activities, which were inhibited upon melatonin administration. These results document that while ROS damage DNA, mitochondria, and cell membranes of granulosa cells, melatonin prevents this mutilation, thereby protecting granulosa cells (Figure 1).

Tamura et al. examined the effect of ROS and melatonin on the maturation process of oocytes from mice [39]. Germinal vesicle (GV)-stage oocytes were cultured with $\mathrm{H}_{2} \mathrm{O}_{2}$. After $12 \mathrm{~h}$ incubation, oocytes with the first polar body (MII stage oocytes) were significantly decreased as a result of the addition of $\mathrm{H}_{2} \mathrm{O}_{2}$ in a dose-dependent manner $(>200 \mu \mathrm{M})$. However, melatonin treatment dose-dependently blocked the inhibitory effect of $\mathrm{H}_{2} \mathrm{O}_{2}$ on oocyte maturation. To further investigate the intracellular role of melatonin, oocytes were incubated with dichlorofluorescein (DCF-DA), a fluorescent dye that identifies ROS [38]. High fluorescence intensities were observed in the presence of $\mathrm{H}_{2} \mathrm{O}_{2}(300 \mu \mathrm{M})$, whereas the increased fluorescence intensity was significantly depressed by melatonin treatment. This is consistent with antioxidative action of melatonin, which reduces ROS in oocytes.

Based on these findings, it appears that melatonin, both locally-synthesized and secreted into the blood by the pineal gland, is taken up by ovarian follicles, where it locally reduces ROS in the follicles and limits oxidative stress, thereby protecting oocytes, as well as granulosa cells, and contributes to oocyte maturation and the luteinization of granulosa cells (Figure 1). 


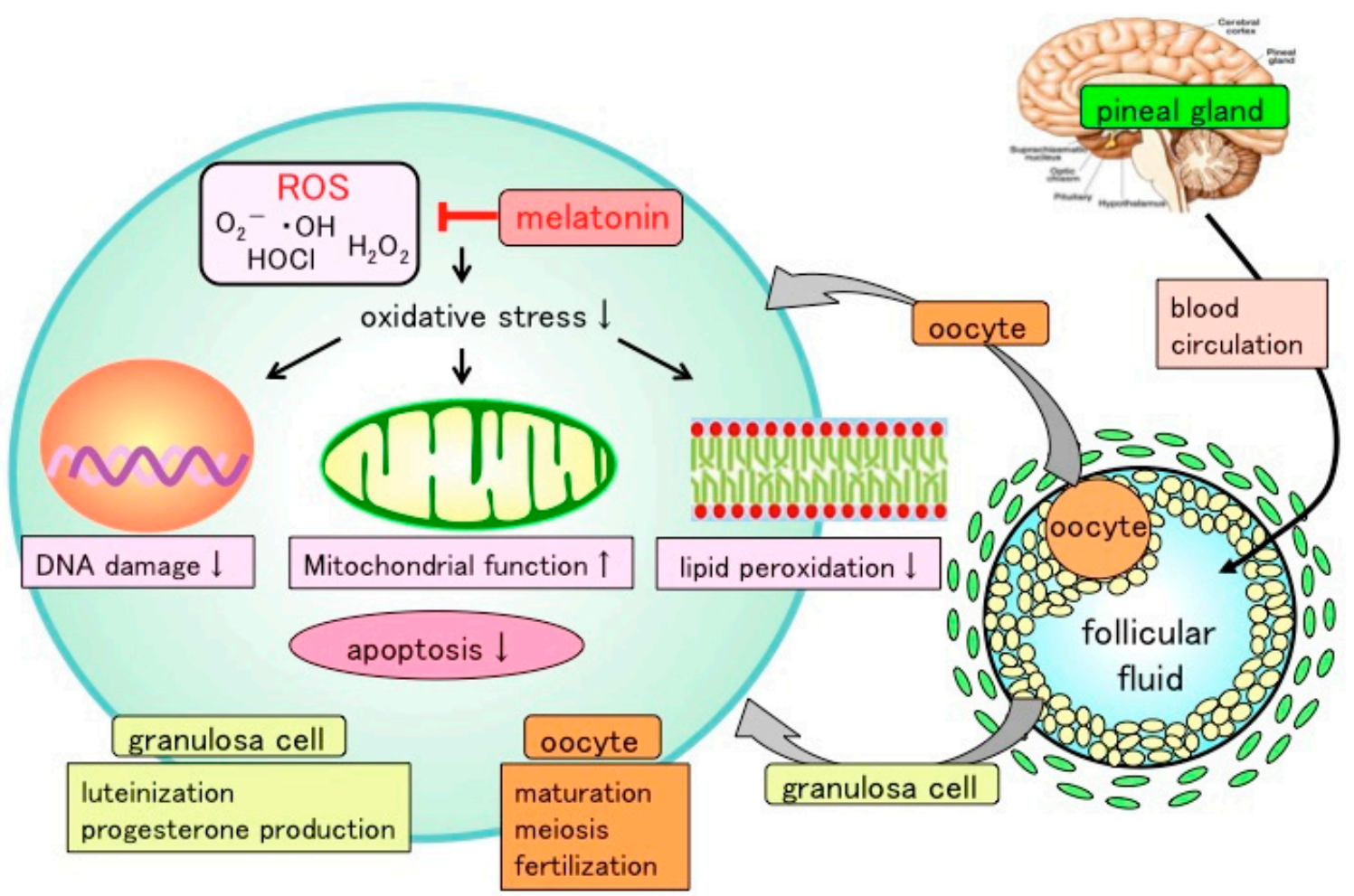

Figure 1. Presumed action of melatonin in ovarian follicle. Melatonin, secreted by pineal gland, is taken up into the follicular fluid from the blood. Reactive oxygen species (ROS) produced within the follicles, especially during the ovulation process, are scavenged by melatonin. Excess amounts of ROS may be involved in oxidative stress of oocyte and granulosa cells. Melatonin reduces the oxidative-stress-induced DNA damage, mitochondrial dysfunction, lipid peroxidation, and apoptosis of granulosa cells, showing that melatonin protects these cells by reducing free radical damage of cellular components including nuclei, mitochondria, and plasma membranes. The balance between ROS and antioxidants (melatonin) within the follicle may be critical for oocyte maturation, meiosis, and luteinization of granulosa cells.

\section{The Clinical Application of Melatonin in the Field of Reproductive Medicine}

In recent years, remarkable advances have been made in assisted reproductive technology (ART) such as IVF-ET for infertility treatment; however, satisfactory conception rates have not been achieved. The major cause of this is attributed to problems in the quality of oocytes [44,45]. In IVF-ET, the frequent unsuccessful cases in which fertilization, embryo development, and implantation do not progress optimally are a result of poor oocyte quality. While the processes underlying reduced oocyte quality have not been fully elucidated, it is thought that oxidative stress caused by ROS in the follicle is a critical factor. In IVF-ET program, in vitro incubation including oocyte incubation, insemination (co-incubation with spermatozoa), fertilization, embryo development, and embryo transfer are performed in a high oxygen environment compared with the in vivo physiological condition. As long-term in vitro incubation conditions have a major negative impact on the quality of the oocyte and embryo, extreme caution must be exercised to control oxidative stress caused by ROS during incubation.

As an application of the antioxidative effects of melatonin for reproductive medicine, it is possible that in vivo administration may improve the quality of oocytes until ovulation (oocyte retrieval) and improve oocyte maturation, fertilization, and embryo development during in vitro incubation when melatonin is added to the incubation medium (Figure 2). 
(1) in vivo

Melatonin administration

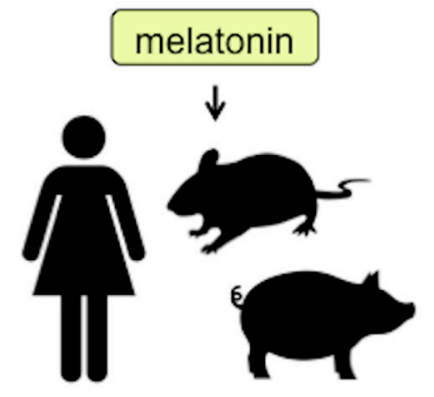

IVE-ET/ICSI program

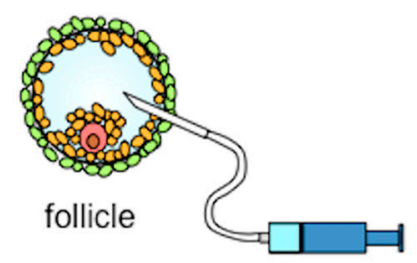

oocyte retrieval
(2) in vitro

Melatonin supplementation to culture media

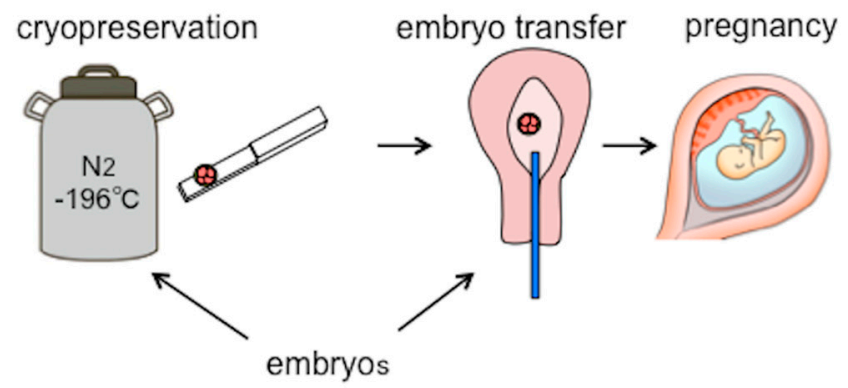

In vitro culture $\cdot$ In vitro fertilization (ovum, embryo)

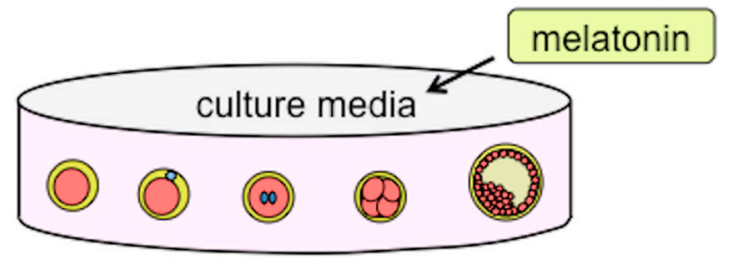

oocyte maturation fertilization embryo development

Figure 2. The potential applications of melatonin in human reproduction. Since the application of melatonin has antioxidant effects in reproductive medicine, there are two possibilities. One is that in vivo melatonin administration to patients before ovulation may improve the oocyte quality. Another possibility is melatonin supplementation added to in vitro culture media to enhance oocyte maturation, fertilization, and embryonic development. IVF-ET: in vitro fertilization and embryo transfer, ICSI: intra-cytoplasmic sperm injection.

\subsection{Melatonin in Assisted Reproductive Technology (ART)}

Follicular melatonin protects granulosa cells and oocytes from ROS. If follicular concentrations of melatonin were increased by administering melatonin to female patients, it may well improve the quality of oocytes. Tamura et al. performed an examination of IVF-ET with infertile patients with poor oocyte quality (fertilization rate $<50 \%$ ) who were divided into two groups, including a treatment group given melatonin tablets ( $3 \mathrm{mg} /$ day) for one month up to the time of oocyte retrieval for the next IVF-ET (melatonin group) and a group without melatonin treatment (control group). In the melatonin treated subjects, the fertilization rate was approximately $50 \%$ (vs. approximately $20 \%$ for the control group) and the pregnancy rate was roughly $20 \%$ (vs. approximately $10 \%$ for the control group), indicating improved outcomes for IVF-ET [39]. It is possible that the administration of melatonin to patients suffering from infertility increases follicular concentrations of melatonin, which thereby inhibits oxidative stress and improves the quality of oocytes, thus improving fertilization and pregnancy rates. After this initial study, other reports also examined whether melatonin therapy improves the clinical outcome of IVF-ET, with the findings likewise also showing that the concurrent use of melatonin increases the number of mature oocytes, the fertilization rate, and number of high-quality embryos [39,46-50] (Table 1). It is suggested that the effects of melatonin include an increased concentration of melatonin in the follicular fluid and a reduced 8-OHdG concentration, which leads to the conclusion that melatonin's multiple antioxidant actions lower oxidative stress in oocytes $[39,50]$. In ART, melatonin would be expected to elevate the pregnancy rate by improving the quality of oocytes as well as promoting the fertilization rate and embryo development. 
Table 1. Effects of melatonin on assisted reproductive technology in humans (in vivo study). M: melatonin; C: control; IVF: IVF: in vitro fertilization; ICSI: intra-cytoplasmic sperm injection; 8-OHdG: 8-hydroxy-2'-deoxyguanosine; FF: follicular fluid; TAC: total antioxidant capacity.

\begin{tabular}{|c|c|c|c|c|c|c|c|}
\hline Patients & Number & Technique & Melatonin Treatment & Result & Mechanisms & Year & Author/Reference \\
\hline infertile women & $115(56 \mathrm{M} / 59 \mathrm{C})$ & IVF-ET & $3 \mathrm{mg} /$ day orally & improved fertilization rate & $\begin{array}{l}\text { reduced } 8-\mathrm{OHdG} \text { in } \\
\mathrm{FF} \text { increased } \mathrm{M} \text { in FF }\end{array}$ & 2008 & Tamura [6] \\
\hline infertile women & $60(30 \mathrm{M} / 30 \mathrm{C})$ & IVF-ET & $3 \mathrm{mg} /$ day orally & $\begin{array}{c}\text { increased mature oocyte } \\
\text { increased good quality embryos }\end{array}$ & & 2011 & Eryilmaz [47] \\
\hline infertile women & $85(40 \mathrm{M} / 45 \mathrm{C})$ & IVF-ET & $3 \mathrm{mg} /$ day orally & $\begin{array}{c}\text { increased mature oocyte } \\
\text { increased good quality embryos }\end{array}$ & & 2012 & Batioglu [46] \\
\hline infertile women & $97(97 \mathrm{M} / 97 \mathrm{C})$ & IVF, ICSI & $3 \mathrm{mg} /$ day orally & $\begin{array}{c}\text { improved fertilization rate } \\
\text { increased good quality embryos }\end{array}$ & & 2014 & Nishihara [49] \\
\hline $\begin{array}{c}\text { infertile women } \\
\text { diminished ovarian reserve }\end{array}$ & $66(32 \mathrm{M} / 24 \mathrm{C})$ & IVF, ICSI & $3 \mathrm{mg} /$ day orally & $\begin{array}{l}\text { increased mature oocyte } \\
\text { increased good quality embryos }\end{array}$ & & 2017 & Jahromi [48] \\
\hline infertile women & $30(10 \mathrm{C} / 10 \mathrm{M}, 10 \mathrm{M})$ & IVF, ICSI & 3 or $6 \mathrm{mg} /$ day orally & $\begin{array}{l}\text { increased no of oocyte retrieved } \\
\text { increased good quality embryos }\end{array}$ & $\begin{array}{c}\text { increased M, TAC in } \\
\text { FF decreased } \\
\text { 8-OHdG in FF }\end{array}$ & 2019 & Espino [50] \\
\hline
\end{tabular}




\subsection{Oocyte Maturation, Embryo Development, and Melatonin}

In studies using oocytes from mice, cows, and pigs, it has been reported that oocyte maturation, fertilization, and embryo development are promoted upon in vitro incubation of oocytes in culture medium supplemented with melatonin (Table 2). As oxygen concentrations are higher in in vitro incubations than in vivo, oxidative stress caused by ROS generated during incubation often has an adverse effect on oocyte maturation and embryo development. The addition melatonin to the culture medium wound detoxifies ROS, thereby reducing oxidative damage so as to protect the oocytes and granulosa cells. Reducing oxidative stress and apoptosis of oocytes and promoting mitochondrial function via melatonin treatment have been shown to improve oocyte maturation, fertilization rate, and rate of blastocyst formation (blastocyst cell count) [51-53]. Furthermore, the effect of oxidative stress induced by substances that generate ROS, such as bisphenol A (BPA) and aflatoxin B1 (AFB1), is reduced when melatonin is added to the culture medium [54,55]. This action of melatonin reduces ROS and oxidative stress due to its direct antioxidative actions.

Because melatonin reduces ROS and oxidative stress via its direct antioxidative functions, it improves cellular integrity (Figure 3). However, indirect effects of melatonin via membrane receptors $(\mathrm{MT} 1, \mathrm{MT} 2)$ and/or nuclear receptors $(\mathrm{ROR} \alpha)$ are also important to understand the processes by which melatonin alters the level of oxidative stress [56,57]. Figure 3 summarizes the mechanism of melatonin that are assumed to improve oocyte maturation and quality based on reports to date. Melatonin membrane receptors (MT1, MT2) are located in oocytes and granulosa cells (cumulus cells) [58-61]; it would be of great interest to determine the intracellular signaling pathway by which melatonin promotes oocyte maturation and embryo development. While some reports have examined these intracellular processes of melatonin in oocytes [62-65], the details remain unclear. It has been reported that melatonin controls the expression of genes related to oocyte maturation including mitochondrial function $[53,60,66,67]$, antioxidative enzymes $[53,59,67,68]$, apoptosis [52,65-69], cumulus cell expansion [51,61,70], and oocyte maturation factors [61,67]. Furthermore, epigenetic mechanisms such as DNA methylation and histone acetylation have also been reported $[59,66,71]$. Further study may identify how these epigenetic mechanisms contribute to oocyte maturation by regulating the expression of some specific genes in oocyte and granulosa cells. In addition to a direct antioxidative action, it is essential to elucidate the detailed mechanisms of melatonin on oocytes and granulosa cells (cumulus cells) that involve both the membrane and nuclear receptors.

ROS play crucial roles in reproductive functions such as the ovulatory process. However, in excess, they may adversely affect oocytes in the form of oxidative stress which would cause infertility. Melatonin existing in follicles may possibly protect oocytes from ROS with its antioxidant activity and its involvement in oocyte maturation, fertilization, and embryo development. The trials of clinical application of melatonin for infertile women have reported improved outcomes of ART. It should be noted that melatonin supplementation could become a new treatment for improving oocyte quality and it may benefit women who suffer from infertility. 
Table 2. Effects of melatonin on assisted reproductive technology under in vitro conditions. COC: cumulus oocyte complex; IVM: in vitro maturation; M II: metaphase II; ROS: reactive oxygen species; MT1, MT2: melatonin membrane receptors; BMP: bone morphogenic protein; PTX3: pentraxin-3; HAS2: hyaluronan synthase 2; EGFR: epidermal growth factor receptors; GSH: glutathione; ATP: adenosine triphosphate; GDF: growth differentiation factor; SOD: superoxide dismutase; GPX: glutathione peroxidase; Bcl-2: B-cell lymphoma-2; GSX: reduced glutathione; OCT4: octamer-binding transcription factor 4; H2AX: histone H2 family member X; H3K4me: methylation of lysine4 on histone H3; H4K27me: methylation of lysine27 on histone H3; CAT: catalase; HSP: heat shock protein; MTNR1A: melatonin receptor 1A; MT: melatonin receptor; 4P-PDOT: 4-phenyl-2-propionamidotetralin; BimEL: Bcl-2 interacting mediator of cell death extra-long; ERK: extracellular signal-regulated kinase; H3K9: histone H3 lysine 9.

\begin{tabular}{|c|c|c|c|c|c|}
\hline Animal & Design & Melatonin Treatment & Result & Year & Author/Reference \\
\hline mouse & vitro COCs & $10^{-6} \mathrm{M}$ & $\begin{array}{c}\text { Cumulus expansion, } \mathrm{M}-\mathrm{II} \uparrow \\
\text { ROS, Acetyla on level of H4k12 } \downarrow \\
\end{array}$ & 2017 & Keshavarzi Somayeh [51] \\
\hline mouse & vitro, IVM, implantation & $10^{-7} \mathrm{M}$ & $\begin{array}{c}\text { blastocyst rate, hatching blastocyst rate and blastocyst cell number } \uparrow \\
\text { pregnancy rate and birth rate } \uparrow \text {, (ROS) production and cellular apoptosis } \downarrow\end{array}$ & 2017 & Tian Xiuzhi [69] \\
\hline sheep & vitro, IVM & $10^{-7} \mathrm{M}$ & $\begin{array}{c}\text { rates of nuclear maturation, cumulus cells expansion, cleavage, and blastocyst } \uparrow \\
\text { MT1 and MT2 were expressed in oocytes, cumulus cells, and granulosa cells } \\
\text { BMP15, PTX3, HAS2, EGFR } \uparrow, \text { cAMP level } \downarrow \text {, cGMP } \uparrow\end{array}$ & 2017 & Tian Xiuzhi [65] \\
\hline bovine & vitro, IVM & $10^{-9} \mathrm{M}$ & $\begin{array}{l}\text { ROS } \downarrow \text {, GSH } \uparrow \text {, mitochondrial normal distribution increase ATP level } \\
\text { upregulated ATPase 6, BMP-15, GDF-9, SOD-1, Gpx-4, and Bcl-2 } \\
\text { downregulated apoptotic gene expression of caspase-3. }\end{array}$ & 2017 & Yang Minghui [68] \\
\hline porcine & vitro IVM COCs & $10^{-7}, 10^{-6}, 10^{-5} \mathrm{M}$ & $\begin{array}{c}\text { oocyte quality, embryo development } \uparrow \\
\text { ROS generation, apoptosis, and DNA damage } \downarrow \text {, GSX, OCT4, H2AX }\end{array}$ & 2018 & Lin Tao [52] \\
\hline bovine & vitro, IVM & $10^{-9} \mathrm{M}$ & $\begin{array}{c}\text { G1 blastocyst } \uparrow \text {, cell number } \uparrow \\
\text { apoptotic cell } \downarrow \\
\text { glutathione content, mitochondrial membrane potential } \uparrow \\
\text { antioxidant gene (SOD2) heat shock protein (HSPB1) } \uparrow\end{array}$ & 2018 & Marques TC [53] \\
\hline porcine & vitro prolonged culture & $10^{-3} \mathrm{M}$ & $\begin{array}{c}\text { blastocyst rate } \uparrow \text { methylation at } \mathrm{H} 3 \mathrm{~K} 4 \mathrm{me} 2 \text { and } \mathrm{H} 3 \mathrm{~K} 27 \mathrm{me} 2 \downarrow \\
\text { imprinted gene NNAT } \downarrow\end{array}$ & 2018 & Nie Junyu [71] \\
\hline bovine & vitro, IVM & $10^{-9} \mathrm{M}$ & $\begin{array}{c}\text { blastocyst, total cell number } \uparrow \text {, apoptotic cell } \downarrow \\
\operatorname{ROS} \downarrow \text {, GSH } \uparrow \text { caspase-3 } \downarrow, \text { BCL-2, XIAP, CAT, HSP70 } \uparrow\end{array}$ & 2018 & Pang Yunwei [66] \\
\hline Goat & vitro, IVM & $10^{-9} \mathrm{M}, 10^{-12} \mathrm{M}$ & $\begin{array}{l}\text { M-II stage, blastocyst } \uparrow, \text { GSH } \uparrow, \text { MTNR1A in cumulus cell and oocytes } \\
\text { DNA methyltransferases (DNMTs) global DNA methylation } \downarrow\end{array}$ & 2018 & Saeedabadi Saghar [63] \\
\hline mouse & vitro, IVM & $10 \mu \mathrm{M}$ & $\begin{array}{c}\text { fertilization rate } \uparrow \\
\text { hyaluronan synthase-2 (HAS2) and Progesterone receptor (PGR) } \uparrow\end{array}$ & 2018 & Ezzati Maryam [70] \\
\hline porcine & vitro COCs & $10^{-9} \mathrm{M}$ & $\begin{array}{c}\text { blastocyst, cell number, cumulus expansion } \uparrow \text {, apoptosis } \downarrow \\
\text { MT2 was expressed in both oocytes and cumulus cells } \\
\text { M effects were abolished when either luzindole or 4P-PDOT (MT antagonist) }\end{array}$ & 2018 & Lee Sanghoon [62] \\
\hline porcine & vitro $\mathrm{COCs}$ & $10^{-9} \mathrm{M}$ & $\begin{array}{l}\text { pro-apoptotic protein BimEL, ERK-mediated phosphorylation } \\
\text { M only promoted the ubiquitination of phosphorylated BimEL } \\
\text { M action was independent of its receptor and its antioxidant properties }\end{array}$ & 2018 & Wang Yingzheng [67] \\
\hline bovine & vitro cloned embryo & $10^{-9} \mathrm{M}$ & $\begin{array}{c}\text { cloned embryo development } \uparrow \\
\text { oxidative stress, apoptosis, mitochondria, chromosome alignment } \\
\text { epigenetic modifications, H3K9 acetylation } \uparrow, \mathrm{H} 3 \mathrm{~K} 9 \text { methylation } \downarrow\end{array}$ & 2019 & An Quanli [56] \\
\hline
\end{tabular}




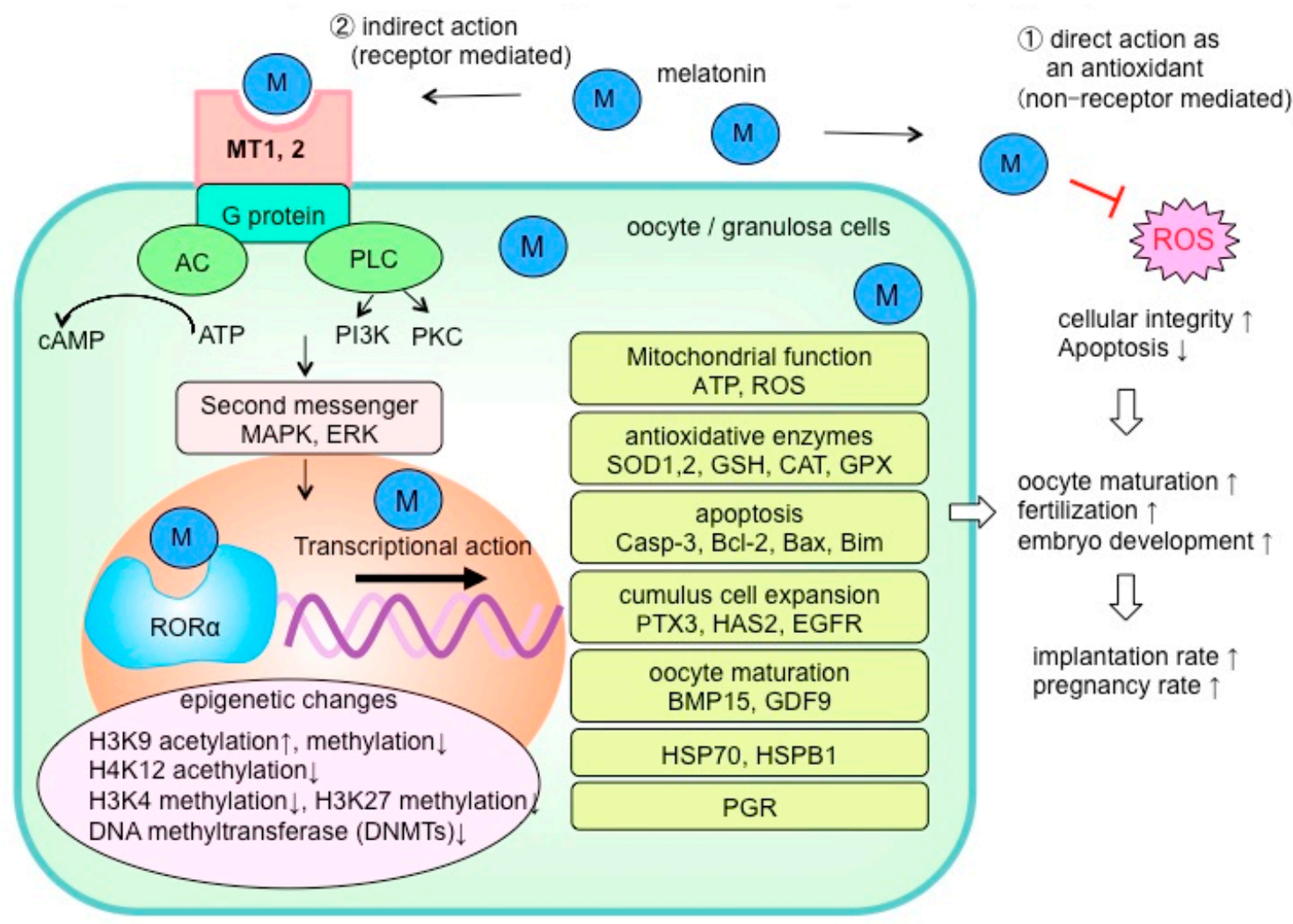

Figure 3. The reported mechanisms by which melatonin improves oocyte quality. The actions of melatonin are to be expected as a direct antioxidant effect to alleviate reactive oxygen species (ROS) and oxidative stress. Another indirect action of melatonin via cell membrane receptors (MT1, MT2) and nuclear receptor $(\operatorname{ROR} \alpha)$ also is considered to be very important for oocyte maturation and embryonic development. It is reported that antioxidant enzyme activity in oocytes, the expression of apoptosis-related factors, expression of genes involved in oocyte maturation and embryonic development, and epigenome changes such as DNA methylation and histone acetylation can be regulated by melatonin supplementation. ROS: reactive oxygen species; AC: adenylyl cyclase; PLC: phospholipase C; ATP: adenosine triphosphate; PI3K: phosphatidylinositol-3 kinase; PKC: protein kinase C; MAPK: mitogen-activated protein kinase; ERK: extracellular signal-regulated kinase; SOD: superoxide dismutase; GSH: glutathione; CAT: catalase; GPX: glutathione peroxidase; Casp: caspase; Bcl-2: B-cell lymphoma-2; Bax: Bcl-2-accociated X protein; Bim: Bcl-2 interacting mediator of cell death; PTX3: pentraxin-3; HAS2: hyaluronan synthase 2; EGFR: epidermal growth factor receptors; BMP: bone morphogenic protein; GDF: growth differentiation factor; HSP: heat shock protein; PGR: progesterone receptor.

\section{Reduced Fertility Associated with Ovarian Aging}

Age is the critical factor that has a major effect on fertility. Infertility caused by ovarian aging is the most important challenge in reproductive medicine. ART success decreases with increased age, with a sudden decline in the pregnancy rate and elevation in the miscarriage rate observed from 35 years of age onwards [72]. Ovarian aging has two problems and includes both reduced oocyte number and reduced oocyte quality. At birth, females are born with 1-2 million oocytes in their ovaries. However, they never produce any new oocytes thereafter and many are continuously being lost. It has been shown that at puberty, the number already is reduced to 100,000-300,000 oocytes, and that by the late 30 s, particularly after 37 years of age, the number of oocytes rapidly decreases.

As women grow older, the quality of each oocyte also is reduced. Oocytes are subjected to various types of damage in an age-dependent manner over the long period of several decades, with dysfunction noted in organelles such as mitochondria and nuclei. This is perceived as poor oocyte quality, and is a 
major cause of frequent unbalanced chromosome segregation in the first meiotic division accompanied by impaired fertilization [73]. Although the mechanisms that cause a decline oocyte quality have not been fully elucidated, it is generally accepted that oxidative stress caused by ROS contributes to age-induced dysfunction of oocyte mitochondria and nuclei. It has also been frequently reported that reduced antioxidative function caused by aging are associated with lower oocyte quality $[74,75]$. While attempts have been made to prevent the lower function and to improve the impaired quality of oocytes, at present no effective method has been established.

\section{Anti-Aging Effects of Melatonin}

Melatonin has drawn attention as an anti-aging molecule $[2,9,23,24]$. The life expectancy of mice treated with melatonin is reportedly prolonged, and the life expectancy of mice with the pineal gland removed is shortened. Therefore, there is a possibility that melatonin has the ability to delay ovarian aging. Tamura et al. examined the protective effect of melatonin on ovarian aging using mice [76]. Female mice were administered melatonin (drinking water containing melatonin) over a period from 10 to 43 weeks of age, after which oocytes were retrieved from follicles and IVF was performed. In 43-week-old control mice, there were fewer follicles of all developmental stages within the ovaries (primordial follicles, primary follicles, secondary follicles, and antral follicles). In the melatonin-treated animals, however, there were more follicles remaining compared to the number in the control animals. Also in the melatonin group, there were more ovulated oocytes, and the age-related decline in the number of oocytes was reduced. The results of IVF indicated that the number of fertilized oocytes and the number of blastocysts declined with age, but were maintained in the melatonin-treated animals. Thus, melatonin also appears to reduce the decline in oocyte quality. The authors also analyzed changes in ovarian gene expression using microarray. The expression of 77 genes decreased with age and were elevated as a result of melatonin treatment. Among these genes, approximately half (40 genes) were involved in ribosomal function. Furthermore, upon performing pathway analysis, the authors extracted eukaryotic initiation factor 2 (eIF2) signaling, which maintains the accuracy of protein synthesis (translation) (Figure 4). This was interpreted to mean that melatonin maintains ribosomal function, accuracies of gene translation, and protein synthesis, thereby slowing the processes of aging. On pathway analysis, the growth arrest and DNA-damage-inducible 45 (GADD45) signaling involved in DNA repair and checkpoint functions were predominantly noted, suggesting that melatonin enhances the mechanism underlying DNA damage repair (Figure 4). Melatonin also suppresses autophagy-related protein (light-chain 3a: LC3a; light-chain 3b: LC3b) by enhancing intracellular pathways, including eIF2, GADD45, and alternative reading frame (ARF) pathways. Furthermore, the network analysis found that melatonin had a stimulatory effect on antioxidative mechanisms. Moreover, the telomere length, which typically decreases during aging, and expressions of the sirtuin longevity genes (SIRT1, SIRT3) were significantly higher in the melatonin-treated animals compared to the control mice. Collectively, the results suggest that, through various mechanisms, melatonin reduces at least some aging processes in the ovaries and oocytes (Figure 4).

Differences in the time of initiating melatonin treatment might result in different anti-aging effects on the ovaries. Therefore, melatonin treatment was started from 23 or 33 weeks of age in mice, and the results of IVF outcomes at 43 weeks of age were analyzed according to the previous report [76] (Figure 5). In the group in which treatment was initiated at 23 weeks, the number of ovulated oocytes ( $8.5 \pm 2.2$, C23 (control group); $16.8 \pm 3.0$, M23 (melatonin group)), fertilization rate $(32.3 \%, \mathrm{C} 23 ; 59.5 \%, \mathrm{M} 23)$, and blastocyst rate $(17.6 \%, \mathrm{C} 23 ; 39.2 \%, \mathrm{M} 23)$ were all significantly higher in the melatonin-supplemented mice than in control animals (Figure 5). These results show that melatonin treatment that began at 23 weeks delayed aging of the ovaries. Conversely, in the group that started at 33 weeks, the number of ovulated oocytes $(9.6 \pm 1.8, \mathrm{C} 33 ; 9.4 \pm 2.7, \mathrm{M} 33)$, fertilization rate $(30.2 \%, \mathrm{C} 33 ; 37.6 \%, \mathrm{M} 33)$, and blastocyst rate $(22.9 \%, \mathrm{C} 33 ; 36.4 \%, \mathrm{M} 33)$ showed no significant difference as a result of melatonin treatment compared to controls (Figure 5). Melatonin was not found to be 
beneficial if melatonin treatment began at 33 weeks. The implication is that, to reduce aging of the ovaries, melatonin supplementation should be initiated well in advance of reproductive deterioration.

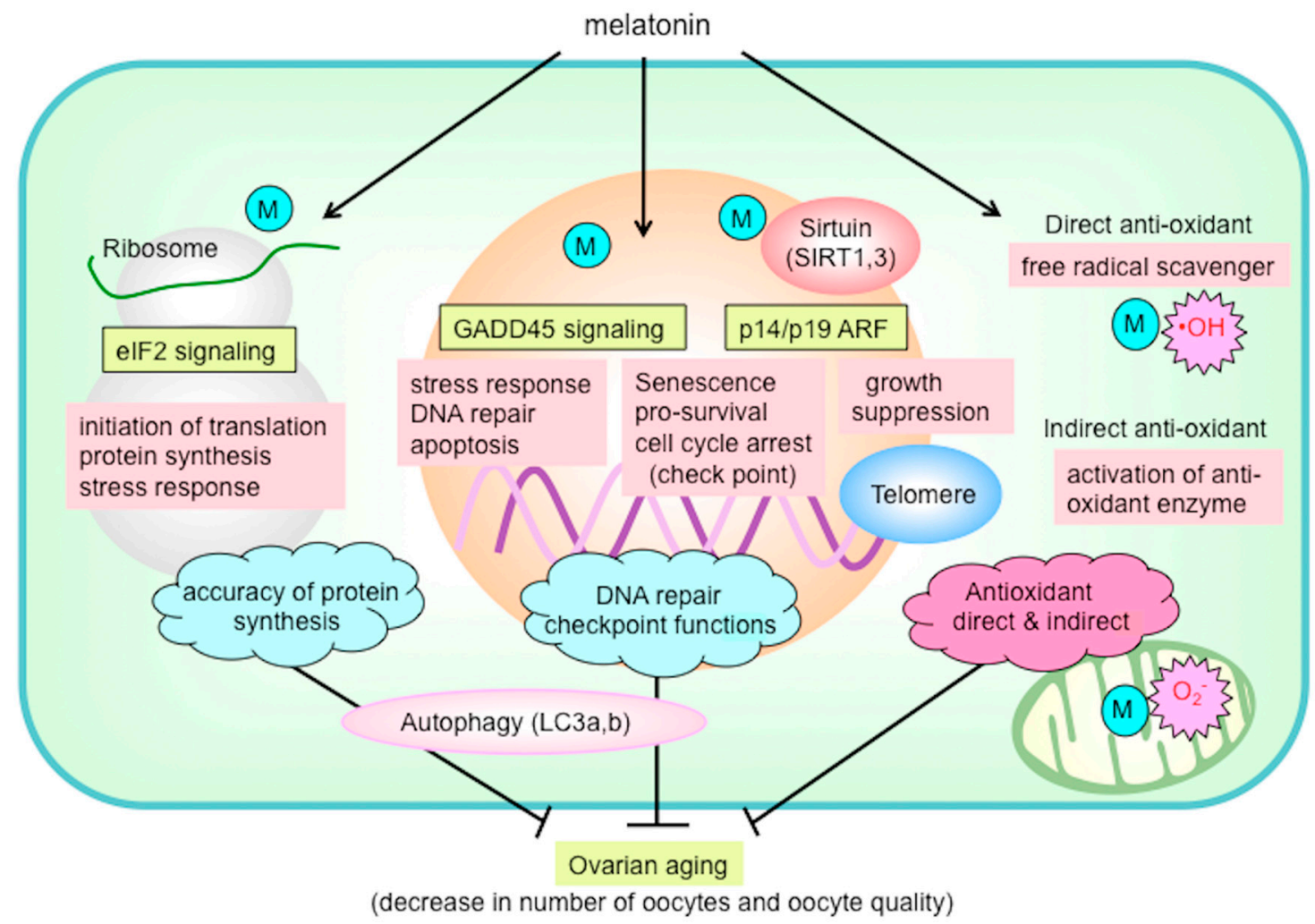

Figure 4. The possible mechanism of melatonin to prevent ovarian aging. Melatonin is likely to reduce ovarian oxidative stress not only by its direct action as a free radical scavenger but also by its indirect action of enhancing the antioxidant enzyme activity. Melatonin enhances eukaryotic initiation factor 2 (eIF2) signaling, which is essential for translation initiation and protein synthesis in ribosomes, and growth arrest and DNA-damage-inducible 45 (GADD45) signaling, which is involved in DNA repair and checkpoint functions. Melatonin also suppresses autophagy-related protein (light-chain 3a, 3b: LC3a, LC3b) by enhancing intracellular pathways including eIF2, GADD45, and alternative reading frame (ARF) pathways. The mRNA expression of sirtuin longevity genes (SIRT1, SIRT3) and telomere length were also enhanced due to melatonin treatment. Melatonin delays ovarian aging by multiple mechanisms including antioxidant action, DNA repair, maintaining telomeres, SIRT family activity, ribosome function, and autophagy. $\mathrm{M}$ : melatonin; $\mathrm{O}_{2}{ }^{\bullet-}$ : superoxide anion; $\mathrm{OH}$ : hydroxyl radical

In another study where melatonin was given to mice for 6-12 months, it was reported that it inhibited the age-related reduction in the number of follicles, litter sizes, and blastocyst rates while improving mitochondrial function, lowering ROS production, reducing oxidative stress, increasing adenosine triphosphate (ATP) production, lowering apoptosis, and elevating antioxidative enzymes, thus demonstrating that melatonin can reduce ovarian aging [77]. A recent study that investigated the effect of melatonin in delaying ovarian aging also reported on the importance of intracellular signaling (MT1/MAPK pathway) via melatonin receptors in oocytes (MT1) to modulate the age-related changes [78].

The mechanisms related to the anti-ovarian aging effects of melatonin are clearly not yet well defined. The clinical application of melatonin for the treatment of humans to improve ovarian physiology should have high priority. Many women suffer from the infertility due to ovarian aging. If long-term melatonin treatment prevents ovarian aging as represented by a decline in the number and quality of oocytes, they would have more oocytes of better quality when they undergo IVF-ET program. Melatonin treatment may make a major contribution to reproductive medicine to improve 
ART outcomes. There are currently no effective methods or established medications that prevent ovarian aging; the administration of melatonin may be a promising candidate for this purpose.

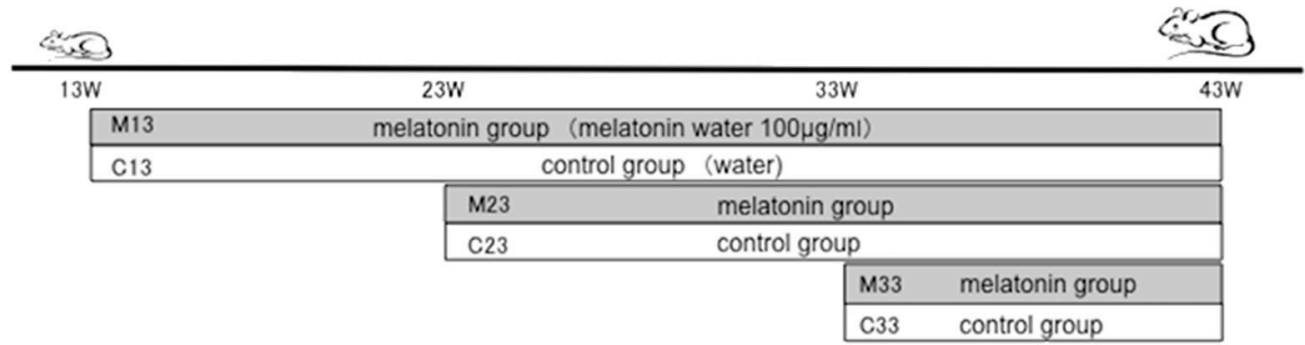

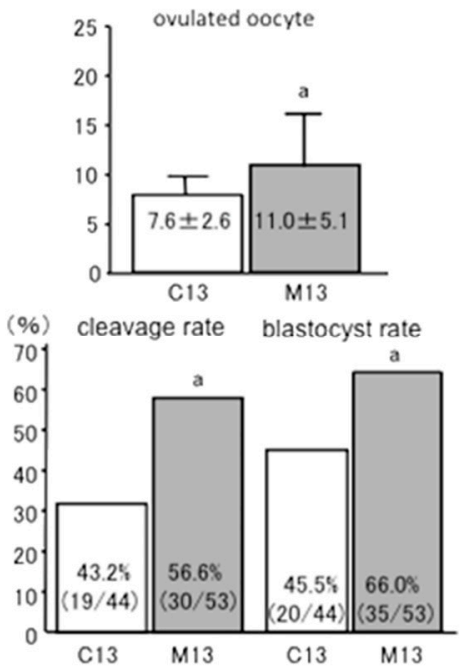

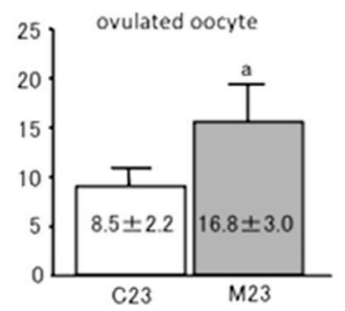

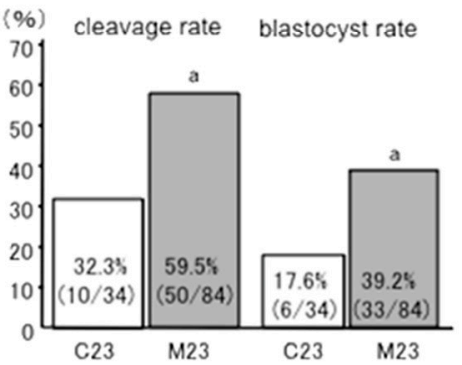

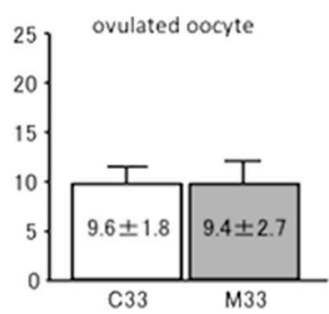

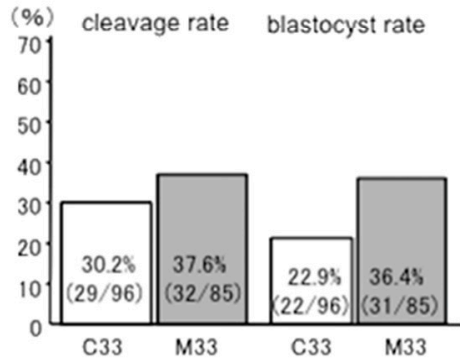

Figure 5. The anti-aging effects of melatonin on ovaries depends on the age of initiation of melatonin treatment. Melatonin treatment was started from 23 weeks (M23 weeks; melatonin group: M23, control group: C23) or 33 weeks (M33 weeks; melatonin group: M33, control group: C33) of age in mice, and the results of IVF outcomes at 43 weeks of age were analyzed. In the 23-week group, the number of ovulated oocytes $(8.5 \pm 2.2, \mathrm{C} 23 ; 16.8 \pm 3.0, \mathrm{M} 23)$, fertilization rate $(32.3 \%, \mathrm{C} 23 ; 59.5 \%$, M23), and blastocyst rate $(17.6 \%, \mathrm{C} 23 ; 39.2 \%, \mathrm{M} 23)$ were all significantly higher in the melatonin group than the control animals, and melatonin was found to have an anti-aging effect on the ovaries. On the other hand, in the 33-week group, the number of ovulated oocytes (9.6 $\pm 1.8, \mathrm{C} 33 ; 9.4 \pm 2.7$, M33), fertilization rate $(30.2 \%, \mathrm{C} 33 ; 37.6 \%, \mathrm{M} 33)$, and blastocyst rate $(22.9 \%, \mathrm{C} 33 ; 36.4 \%$, M33) showed no significant difference between the melatonin treated and control animals.

Author Contributions: H.T.: contributed to the design of the study, acquisition of data, analysis and interpretation of data, and drafting the article. Y.S., Y.M., M.S., M.J., M.T. and S.S.: in vivo and in vitro experiment, analysis and interpretation of the data. I.T., R.M., T.T., and A.T.: participation in study design, execution, analysis, manuscript drafting. R.J.R.: contribution to the concept of the study, interpretation of data, revising the article critically for important intellectual content. N.S. coordinated and supervised the study. All authors read and approved the final manuscript.

Funding: This work was supported in part by Japan Society for the Promotion of Science (JSPS) KAKENHI Grants 25462559, 26670726, and 16K11091 for Scientific Research from the Ministry of Education, Science, and Culture, Japan.

Ethics Approval and Consent to Participate: All experimental protocols were approved by the Committee for Ethics on Animal Experimentation (No47-019, 1 April 2016) and performed under the Guidelines for Animal Experiments at Yamaguchi University Graduate School of Medicine in accordance with Law No. 105 and Noti cation No. 6 of the Japanese Government, and the study was conducted according to guidelines described in the Declaration of Helsinki.

Conflicts of Interest: The authors declare no conflict of interest. 


\section{References}

1. Zhao, D.; Yu, Y.; Shen, Y.; Liu, Q.; Zhao, Z.; Sharma, R.; Reiter, R.J. Melatonin synthesis and function: Evolutionary history in animals and plants. Front. Endocrinol. 2019, 10, 249. [CrossRef]

2. Reiter, R.J.; Tan, D.X.; Galano, A. Melatonin: Exceeding expectations. Physiology (Bethesda) 2014, 29, 325-333. [CrossRef] [PubMed]

3. Acuna-Castroviejo, D.; Escames, G.; Venegas, C.; Diaz-Casado, M.E.; Lima-Cabello, E.; Lopez, L.C.; Rosales-Corral, S.; Tan, D.X.; Reiter, R.J. Extrapineal melatonin: Sources, regulation, and potential functions. Cell. Mol. Life Sci. 2014, 71, 2997-3025. [CrossRef] [PubMed]

4. Majidinia, M.; Reiter, R.J.; Shakouri, S.K.; Yousefi, B. The role of melatonin, a multitasking molecule, in retarding the processes of ageing. Ageing Res. Rev. 2018, 47, 198-213. [CrossRef]

5. Otsuka, F. Modulation of bone morphogenetic protein activity by melatonin in ovarian steroidogenesis. Reprod. Med. Biol. 2018, 17, 228-233. [CrossRef]

6. Tamura, H.; Nakamura, Y.; Narimatsu, A.; Yamagata, Y.; Takasaki, A.; Reiter, R.J.; Sugino, N. Melatonin treatment in peri- and postmenopausal women elevates serum high-density lipoprotein cholesterol levels without influencing total cholesterol levels. J. Pineal Res. 2008, 45, 101-105. [CrossRef]

7. Tamura, H.; Nakamura, Y.; Takiguchi, S.; Kashida, S.; Yamagata, Y.; Sugino, N.; Kato, H. Melatonin directly suppresses steroid production by preovulatory follicles in the cyclic hamster. J. Pineal Res. 1998, 25, $135-141$. [CrossRef]

8. Vriend, J.; Reiter, R.J. Melatonin, bone regulation and the ubiquitin-proteasome connection: A review. Life Sci. 2016, 145, 152-160. [CrossRef]

9. Zhao, C.N.; Wang, P.; Mao, Y.M.; Dan, Y.L.; Wu, Q.; Li, X.M.; Wang, D.G.; Davis, C.; Hu, W.; Pan, H.F. Potential role of melatonin in autoimmune diseases. Cytokine Growth Factor Rev. 2019, 48, 1-10. [CrossRef]

10. Favero, G.; Moretti, E.; Bonomini, F.; Reiter, R.J.; Rodella, L.F.; Rezzani, R. Promising antineoplastic actions of melatonin. Front. Pharmacol. 2018, 9, 1086. [CrossRef]

11. Reiter, R.J.; Rosales-Corral, S.A.; Tan, D.X.; Acuna-Castroviejo, D.; Qin, L.; Yang, S.F.; Xu, K. Melatonin, a full service anti-cancer agent: Inhibition of initiation, progression and metastasis. Int. J. Mol. Sci. 2017, 18, 834. [CrossRef] [PubMed]

12. Sanchez-Barcelo, E.J.; Rueda, N.; Mediavilla, M.D.; Martinez-Cue, C.; Reiter, R.J. Clinical uses of melatonin in neurological diseases and mental and behavioural disorders. Curr. Med. Chem. 2017, 24, 3851-3878. [CrossRef] [PubMed]

13. Cipolla-Neto, J.; Amaral, F.G.; Afeche, S.C.; Tan, D.X.; Reiter, R.J. Melatonin, energy metabolism, and obesity: A review. J. Pineal Res. 2014, 56, 371-381. [CrossRef] [PubMed]

14. Favero, G.; Franceschetti, L.; Bonomini, F.; Rodella, L.F.; Rezzani, R. Melatonin as an anti-inflammatory agent modulating inflammasome activation. Int. J. Endocrinol. 2017, 1835195. [CrossRef]

15. Ma, N.; Zhang, J.; Reiter, R.J.; Ma, X. Melatonin mediates mucosal immune cells, microbial metabolism, and rhythm crosstalk: A therapeutic target to reduce intestinal inflammation. Med. Res. Rev. 2019. [CrossRef]

16. Moradkhani, F.; Moloudizargari, M.; Fallah, M.; Asghari, N.; Heidari Khoei, H.; Asghari, M.H. Immunoregulatory role of melatonin in cancer. J. Cell. Physiol. 2020, 235, 745-757. [CrossRef]

17. Alghamdi, B.S. The neuroprotective role of melatonin in neurological disorders. J. Neurosci. Res. 2018, 96, 1136-1149. [CrossRef]

18. Cardinali, D.P. Melatonin: Clinical perspectives in neurodegeneration. Front. Endocrinol. 2019, $10,480$. [CrossRef]

19. Karamitri, A.; Jockers, R. Melatonin in type 2 diabetes mellitus and obesity. Nat. Rev. Endocrinol. 2019, 15, 105-125. [CrossRef]

20. Wu, H.; Liu, J.; Yin, Y.; Zhang, D.; Xia, P.; Zhu, G. Therapeutic opportunities in colorectal cancer: Focus on melatonin antioncogenic action. BioMed Res. Int. 2019, 2019, 9740568. [CrossRef]

21. Alston, M.; Cain, S.W.; Rajaratnam, S.M.W. Advances of melatonin-based therapies in the treatment of disturbed sleep and mood. Handb. Exp. Pharmacol. 2019, 253, 305-319. [CrossRef] [PubMed]

22. Reiter, R.J.; Tan, D.X.; Rosales-Corral, S.; Galano, A.; Zhou, X.J.; Xu, B. Mitochondria: Central organelles for melatonin's antioxidant and anti-aging actions. Molecules 2018, 23, 509. [CrossRef] [PubMed] 
23. Hardeland, R.; Reiter, R.J.; Poeggeler, B.; Tan, D.X. The significance of the metabolism of the neurohormone melatonin: Antioxidative protection and formation of bioactive substances. Neurosci. Biobehav. Rev. 1993, 17, 347-357. [CrossRef]

24. Poeggeler, B.; Reiter, R.J.; Tan, D.X.; Chen, L.D.; Manchester, L.C. Melatonin, hydroxyl radical-mediated oxidative damage, and aging: A hypothesis. J. Pineal Res. 1993, 14, 151-168. [CrossRef]

25. Reiter, R.J. Functional pleiotropy of the neurohormone melatonin: Antioxidant protection and neuroendocrine regulation. Front. Neuroendocrinol. 1995, 16, 383-415. [CrossRef]

26. Acuna-Castroviejo, D.N.-N.M.; Reiter, R.J.; Escames, G. Melatonin actions in the heart; more than a hormone. Melatonin Res. 2018, 1, 21-26. [CrossRef]

27. Leon, J.; Acuna-Castroviejo, D.; Escames, G.; Tan, D.X.; Reiter, R.J. Melatonin mitigates mitochondrial malfunction. J. Pineal Res. 2005, 38, 1-9. [CrossRef]

28. Paradies, G.; Petrosillo, G.; Paradies, V.; Reiter, R.J.; Ruggiero, F.M. Melatonin, cardiolipin and mitochondrial bioenergetics in health and disease. J. Pineal Res. 2010, 48, 297-310. [CrossRef]

29. Reiter, R.J.; Paredes, S.D.; Manchester, L.C.; Tan, D.X. Reducing oxidative/nitrosative stress: A newly-discovered genre for melatonin. Crit. Rev. Biochem. Mol. Biol. 2009, 44, 175-200. [CrossRef]

30. Venegas, C.; Garcia, J.A.; Escames, G.; Ortiz, F.; Lopez, A.; Doerrier, C.; Garcia-Corzo, L.; Lopez, L.C.; Reiter, R.J.; Acuna-Castroviejo, D. Extrapineal melatonin: Analysis of its subcellular distribution and daily fluctuations. J. Pineal Res. 2012, 52, 217-227. [CrossRef]

31. Rodriguez, C.; Mayo, J.C.; Sainz, R.M.; Antolin, I.; Herrera, F.; Martin, V.; Reiter, R.J. Regulation of antioxidant enzymes: A significant role for melatonin. J. Pineal Res. 2004, 36, 1-9. [CrossRef] [PubMed]

32. Tan, D.X.R.R. Mitochondria: The birth place, battle ground and the site of melatonin metabolism in cells. Melatonin Res. 2019, 2, 44-46. [CrossRef]

33. Reiter, R.J.; Tan, D.X.; Manchester, L.C.; Lopez-Burillo, S.; Sainz, R.M.; Mayo, J.C. Melatonin: Detoxification of oxygen and nitrogen-based toxic reactants. Adv. Exp. Med. Biol. 2003, 527, 539-548. [CrossRef] [PubMed]

34. Tan, D.X.; Manchester, L.C.; Terron, M.P.; Flores, L.J.; Reiter, R.J. One molecule, many derivatives: A never-ending interaction of melatonin with reactive oxygen and nitrogen species? J. Pineal Res. 2007, 42, 28-42. [CrossRef]

35. Moniruzzaman, M.; Ghosal, I.; Das, D. and Chakraborty, S.B. Melatonin ameliorates H2O2-induced oxidative stress through modulation of Erk/Akt/NFkB pathway. Biol. Res. 2018, 51, 17. [CrossRef]

36. Kala, M.; Shaikh, M.V.; Nivsarkar, M. Equilibrium between anti-oxidants and reactive oxygen species: A requisite for oocyte development and maturation. Reprod. Med. Biol. 2017, 16, 28-35. [CrossRef]

37. He, C.; Wang, J.; Zhang, Z.; Yang, M.; Li, Y.; Tian, X.; Ma, T.; Tao, J.; Zhu, K.; Song, Y.; et al. Mitochondria synthesize melatonin to ameliorate its function and improve mice oocyte's quality under in vitro conditions. Int. J. Mol. Sci. 2016, 17, 939. [CrossRef]

38. Tamura, H.; Takasaki, A.; Taketani, T.; Tanabe, M.; Kizuka, F.; Lee, L.; Tamura, I.; Maekawa, R.; Aasada, H.; Yamagata, Y.; et al. The role of melatonin as an antioxidant in the follicle. J. Ovarian. Res. 2012, 5, 5. [CrossRef]

39. Tamura, H.; Takasaki, A.; Miwa, I.; Taniguchi, K.; Maekawa, R.; Asada, H.; Taketani, T.; Matsuoka, A.; Yamagata, Y.; Shimamura, K.; et al. Oxidative stress impairs oocyte quality and melatonin protects oocytes from free radical damage and improves fertilization rate. J. Pineal Res. 2008, 44, 280-287. [CrossRef]

40. Cruz, M.H.; Leal, C.L.; Cruz, J.F.; Tan, D.X.; Reiter, R.J. Essential actions of melatonin in protecting the ovary from oxidative damage. Theriogenology 2014, 82, 925-932. [CrossRef]

41. Wurtman, R.J.; Axelrod, J.; Potter, L.T. The uptake of H3-melatonin in endocrine and nervous tissues and the effects of constant light exposure. J. Pharmacol. Exp. Ther. 1964, 143, 314-318. [PubMed]

42. Nakamura, Y.; Tamura, H.; Takayama, H.; Kato, H. Increased endogenous level of melatonin in preovulatory human follicles does not directly influence progesterone production. Fertil. Steril. 2003, 80, 1012-1016. [CrossRef]

43. Tanabe, M.; Tamura, H.; Taketani, T.; Okada, M.; Lee, L.; Tamura, I.; Maekawa, R.; Asada, H.; Yamagata, Y.; Sugino, N. Melatonin protects the integrity of granulosa cells by reducing oxidative stress in nuclei, mitochondria, and plasma membranes in mice. J. Reprod. Dev. 2015, 61, 35-41. [CrossRef] [PubMed]

44. Ge, Z.J.; Schatten, H.; Zhang, C.L.; Sun, Q.Y. Oocyte ageing and epigenetics. Reproduction 2015, 149, R103-R114. [CrossRef] [PubMed]

45. Liu, X.J. Targeting oocyte maturation to improve fertility in older women. Cell Tissue Res. 2015, 363, 57-68. [CrossRef] 
46. Batioglu, A.S.; Sahin, U.; Gurlek, B.; Ozturk, N.; Unsal, E. The efficacy of melatonin administration on oocyte quality. Gynecol. Endocrinol. 2012, 28, 91-93. [CrossRef]

47. Eryilmaz, O.G.; Devran, A.; Sarikaya, E.; Aksakal, F.N.; Mollamahmutoglu, L.; Cicek, N. Melatonin improves the oocyte and the embryo in IVF patients with sleep disturbances, but does not improve the sleeping problems. J. Assist. Reprod Genet. 2011, 28, 815-820. [CrossRef]

48. Jahromi, B.N.; Sadeghi, S.; Alipour, S.; Parsanezhad, M.E.; Alamdarloo, S.M. Effect of melatonin on the outcome of assisted reproductive technique cycles in women with diminished ovarian reserve: A double-blinded randomized clinical trial. Iran. J. Med. Sci. 2017, 42, 73-78.

49. Nishihara, T.; Hashimoto, S.; Ito, K.; Nakaoka, Y.; Matsumoto, K.; Hosoi, Y.; Morimoto, Y. Oral melatonin supplementation improves oocyte and embryo quality in women undergoing in vitro fertilization-embryo transfer. Gynecol. Endocrinol. 2014, 30, 359-362. [CrossRef]

50. Espino, J.; Macedo, M.; Lozano, G.; Ortiz, A.; Rodriguez, C.; Rodriguez, A.B.; Bejarano, I. Impact of melatonin supplementation in women with unexplained infertility undergoing fertility treatment. Antioxidants 2019, 8 , 338. [CrossRef]

51. Keshavarzi, S.; Salehi, M.; Farifteh-Nobijari, F.; Hosseini, T.; Hosseini, S.; Ghazifard, A.; Ghaffari Novin, M.; Fallah-Omrani, V.; Nourozian, M.; Hosseini, A. Melatonin modifies histone acetylation during in vitro maturation of mouse oocytes. Cell. J. 2018, 20, 244-249. [CrossRef] [PubMed]

52. Lin, T.; Lee, J.E.; Kang, J.W.; Oqani, R.K.; Cho, E.S.; Kim, S.B.; Jin, D., II. Melatonin supplementation during prolonged in vitro maturation improves the quality and development of poor-quality porcine oocytes via anti-oxidative and anti-apoptotic effects. Mol. Reprod Dev. 2018, 85, 665-681. [CrossRef] [PubMed]

53. Marques, T.C.; da Silva Santos, E.C.; Diesel, T.O.; Leme, L.O.; Martins, C.F.; Dode, M.; Alves, B.G.; Costa, F.; de Oliveira, E.B.; Gambarini, M.L. Melatonin reduces apoptotic cells, SOD2 and HSPB1 and improves the in vitro production and quality of bovine blastocysts. Reprod. Domest. Anim. 2018, 53, 226-236. [CrossRef] [PubMed]

54. Cheng, L.; Qin, Y.; Hu, X.; Ren, L.; Zhang, C.; Wang, X.; Wang, W.; Zhang, Z.; Hao, J.; Guo, M.; et al. Melatonin protects in vitro matured porcine oocytes from toxicity of Aflatoxin B1. J. Pineal Res. 2019, 66, e12543. [CrossRef] [PubMed]

55. Park, H.J.; Park, S.Y.; Kim, J.W.; Yang, S.G.; Kim, M.J.; Jegal, H.G.; Kim, I.S.; Choo, Y.K.; Koo, D.B. Melatonin improves oocyte maturation and mitochondrial functions by reducing bisphenol A-derived superoxide in porcine oocytes in vitro. Int. J. Mol. Sci. 2018, 19, 3422. [CrossRef]

56. An, Q.; Peng, W.; Cheng, Y.; Lu, Z.; Zhou, C.; Zhang, Y.; Su, J. Melatonin supplementation during in vitro maturation of oocyte enhances subsequent development of bovine cloned embryos. J. Cell. Physiol. 2019, 234, 17370-17381. [CrossRef] [PubMed]

57. Lee, S.; Jin, J.X.; Taweechaipaisankul, A.; Kim, G.A.; Ahn, C.; Lee, B.C. Melatonin influences the sonic hedgehog signaling pathway in porcine cumulus oocyte complexes. J. Pineal Res. 2017, 63, e12424. [CrossRef]

58. Pang, Y.; Zhao, S.; Sun, Y.; Jiang, X.; Hao, H.; Du, W.; Zhu, H. Protective effects of melatonin on the in vitro developmental competence of bovine oocytes. Anim. Sci. J. 2018, 89, 648-660. [CrossRef]

59. Fang, Y.; Zhang, J.; Li, Y.; Guo, X.; Li, J.; Zhong, R.; Zhang, X. Melatonin-induced demethylation of antioxidant genes increases antioxidant capacity through RORalpha in cumulus cells of prepubertal lambs. Free Radic. Biol. Med. 2019, 131, 173-183. [CrossRef]

60. Fang, Y.; Deng, S.; Zhang, J.; Liu, H.; Li, Y.; Zhang, X.; Liu, Y. Melatonin-mediated development of ovine cumulus cells, perhaps by regulation of DNA methylation. Molecules 2018, 23, 494. [CrossRef]

61. Liu, L.; Labani, N.; Cecon, E.; Jockers, R. Melatonin target proteins: Too many or not enough? Front. Endocrinol. 2019, 10, 791. [CrossRef] [PubMed]

62. Lee, S.; Jin, J.X.; Taweechaipaisankul, A.; Kim, G.A.; Lee, B.C. Stimulatory effects of melatonin on porcine in vitro maturation are mediated by MT2 receptor. Int. J. Mol. Sci. 2018, 19, 1581. [CrossRef] [PubMed]

63. Saeedabadi, S.; Abazari-Kia, A.H.; Rajabi, H.; Parivar, K.; Salehi, M. Melatonin improves the developmental competence of goat oocytes. Int. J. Fertil. Steril. 2018, 12, 157-163. [CrossRef] [PubMed]

64. Soto-Heras, S.; Catala, M.G.; Roura, M.; Menendez-Blanco, I.; Piras, A.R.; Izquierdo, D.; Paramio, M.T. Effects of melatonin on oocyte developmental competence and the role of melatonin receptor 1 in juvenile goats. Reprod. Domest. Anim. 2019, 54, 381-390. [CrossRef] [PubMed] 
65. Tian, X.; Wang, F.; Zhang, L.; He, C.; Ji, P.; Wang, J.; Zhang, Z.; Lv, D.; Abulizi, W.; Wang, X.; et al. Beneficial effects of melatonin on the in vitro maturation of sheep oocytes and its relation to melatonin receptors. Int. J. Mol. Sci. 2017, 18, 824. [CrossRef]

66. Pang, Y.W.; Jiang, X.L.; Wang, Y.C.; Wang, Y.Y.; Hao, H.S.; Zhao, S.J.; Du, W.H.; Zhao, X.M.; Wang, L.; Zhu, H.B. Melatonin protects against paraquat-induced damage during in vitro maturation of bovine oocytes. J. Pineal Res. 2019, 66, e12532. [CrossRef]

67. Wang, Y.; Zeng, S. Melatonin Promotes Ubiquitination of Phosphorylated pro-apoptotic protein Bcl-2-interacting mediator of cell death-extra long (BimEL) in porcine granulosa cells. Int. J. Mol. Sci. 2018, 19, 3431. [CrossRef]

68. Yang, M.; Tao, J.; Chai, M.; Wu, H.; Wang, J.; Li, G.; He, C.; Xie, L.; Ji, P.; Dai, Y.; et al. Melatonin improves the quality of inferior bovine oocytes and promoted their subsequent IVF embryo development: Mechanisms and Results. Molecules 2017, 22, 2059. [CrossRef]

69. Tian, X.; Wang, F.; Zhang, L.; Ji, P.; Wang, J.; Lv, D.; Li, G.; Chai, M.; Lian, Z.; Liu, G. Melatonin promotes the in vitro development of microinjected pronuclear mouse embryos via its anti-oxidative and anti-apoptotic effects. Int. J. Mol. Sci. 2017, 18, 988. [CrossRef]

70. Ezzati, M.; Roshangar, L.; Soleimani Rad, J.; Karimian, N. Evaluating the effect of melatonin on HAS2, and PGR expression, as well as cumulus expansion, and fertility potential in mice. Cell. J. 2018, 20, 108-112. [CrossRef]

71. Nie, J.; Xiao, P.; Wang, X.; Yang, X.; Xu, H.; Lu, K.; Lu, S.; Liang, X. Melatonin prevents deterioration in quality by preserving epigenetic modifications of porcine oocytes after prolonged culture. Aging (Albany N.Y.) 2018, 10, 3897-3909. [CrossRef] [PubMed]

72. Younis, J.S. Ovarian aging and implications for fertility female health. Minerva Endocrinol. 2012, 37, 41-57. [PubMed]

73. Pellestor, F.; Andreo, B.; Arnal, F.; Humeau, C.; Demaille, J. Maternal aging and chromosomal abnormalities: New data drawn from in vitro unfertilized human oocytes. Hum. Genet. 2003, 112, 195-203. [CrossRef] [PubMed]

74. Zhang, T.; Xi, Q.; Wang, D.; Li, J.; Wang, M.; Li, D.; Zhu, L.; Jin, L. Mitochondrial dysfunction and endoplasmic reticulum stress involved in oocyte aging: An analysis using single-cell RNA-sequencing of mouse oocytes. J. Ovarian. Res. 2019, 12, 53. [CrossRef] [PubMed]

75. Lim, J.; Luderer, U. Oxidative damage increases and antioxidant gene expression decreases with aging in the mouse ovary. Biol. Reprod. 2011, 84, 775-782. [CrossRef] [PubMed]

76. Tamura, H.; Kawamoto, M.; Sato, S.; Tamura, I.; Maekawa, R.; Taketani, T.; Aasada, H.; Takaki, E.; Nakai, A.; Reiter, R.J.; et al. Long-term melatonin treatment delays ovarian aging. J. Pineal Res. 2017, 62, e12381. [CrossRef] [PubMed]

77. Song, C.; Peng, W.; Yin, S.; Zhao, J.; Fu, B.; Zhang, J.; Mao, T.; Wu, H.; Zhang, Y. Melatonin improves age-induced fertility decline and attenuates ovarian mitochondrial oxidative stress in mice. Sci. Rep. 2016, 6, 35165. [CrossRef]

78. Zhang, L.; Zhang, Z.; Wang, J.; Lv, D.; Zhu, T.; Wang, F.; Tian, X.; Yao, Y.; Ji, P.; Liu, G. Melatonin regulates the activities of ovary and delays the fertility decline in female animals via MT1/AMPK pathway. J. Pineal Res. 2019, 66, e12550. [CrossRef]

(C) 2020 by the authors. Licensee MDPI, Basel, Switzerland. This article is an open access article distributed under the terms and conditions of the Creative Commons Attribution (CC BY) license (http://creativecommons.org/licenses/by/4.0/). 